ISSN 0258-7122 (Print), 2408-8293 (Online)

Bangladesh J. Agril. Res. 41(2): 323-334, June 2016

\title{
EFFECT OF FOLIAR APPLICATION OF ZINC ON YIELD OF WHEAT GROWN BY AVOIDING IRRIGATION AT DIFFERENT GROWTH STAGES
}

\author{
S. SULTANA ${ }^{1}$, H. M. NASER ${ }^{2}$, N. C. SHIL ${ }^{3}$ \\ S. AKHTER ${ }^{2}$ AND R. A. BEGUM ${ }^{5}$
}

\begin{abstract}
A field experiment was carried out at micronutrient experimental field of Soil Science Division, BARI, Joydebpur, Gazipur to study the effect of foliar application of zinc on yield of wheat (BARI gom-25) grown by skipping irrigation at different growth stages of the crop. The experiment was designed in a split plot design on sixteen treatments comprising four irrigation treatments (regular irrigation, skipped irrigation at crown root initiation, skipped irrigation at booting stage and skipped irrigation at grain filling stages of wheat growth) and four foliar application of zinc $(0.0 \%, 0.02 \%, 0.04 \%$ and $0.06 \%$ of zinc). Zinc Sulphate Monohydrate $\left(\mathrm{ZnSO}_{4} \cdot \mathrm{H}_{2} \mathrm{O}\right)$ was used as a source of $\mathrm{Zn}$. The interaction effect of irrigation and foliar application of zinc significantly influenced the yield and yield components of wheat. The highest yield (5.59 $\mathrm{t}$ $\mathrm{ha}^{-1}$ ) was recorded in normal irrigation which was identical with skipping irrigation at flowering and heading stage with $0.06 \%$ foliar application of zinc. Skipping irrigation at crown root initiation stage had the most negative effect on growth and yield. Skipping irrigation at flowering and heading stage of wheat with $0.04 \%$ foliar application of zinc gave the identical yield in regular irrigation with $0.04 \%$ and $0.06 \%$ foliar application of zinc. Thus, foliar application of zinc played a major role on yield and yield components of wheat at later stages of growth. The response of foliar application of $\mathrm{Zn}$ was positive and quadrate in nature. The optimum dose was appeared as $0.04 \%$ foliar application of zinc for grain yield of wheat in the study area of Joydebpur, Gazipur (AEZ-28).
\end{abstract}

Keywords: Foliar, Zinc, Irrigation, Wheat and Yield.

\section{Introduction}

Wheat is an important cereal crop and serves as a staple food in many countries of the world. Most of the wheat-growing areas in the world suffer from low water supply and irregular distribution of rainfall during the growing season (Bagci et al., 2007). Drought stress is also a serious abiotic stress factor limiting crop production in Bangladesh. However, the stress response depends upon the intensity, rate and duration of exposure and the stage of crop growth (Wajid et al., 2004). Depending on the time, amount and distribution of the precipitation,

${ }^{1}$ Scientific Officer, Soil Science Division, Bangladesh Agricultural Research Institute (BARI), Joydebpur, Gazipur-1701, ${ }^{2-4}$ Principal Scientific Officer, Soil Science Division, BARI, Joydebpur, Gazipur-1701, ${ }^{5}$ Chief Scientific Officer and Head, Soil Science Division, BARI, Joydebpur, Gazipur-1701, Bangladesh. 
drought stress results in substantial yield losses and in combination with $\mathrm{Zn}$ deficiency the decreases in yield becomes more severe (Ekiz et al., 1998). When considering a water regime for a crop, it is wise to understand the sensitive growth stages for water and the water requirement of the crop. In order to achieve maximum yield and, maintaining adequate soil moisture condition during moisture-sensitive stages of growth so irrigation water may be saved if soil water could be depleted to a greater extent during certain growth stages without affecting yield (Thalooth et al., 2006).

As well documented by plant physiologists, zinc exerts a great influence on basic plant life processes, such as (i) nitrogen metabolism - uptake of nitrogen and protein quality; (ii) photosynthesis - chlorophyll synthesis, carbon anhydrase activity; (iii) resistance to abiotic and biotic stresses - protection against oxidative damage (Cakmak, 2008). Zinc is known to have an important role either as a metal component of enzymes or as a functional, structural or regulatory cofactor of a large number of enzymes (Grotz and Guerinot, 2006). Zinc also plays an important role in the production of biomass (Kaya and Higgs, 2002; Cakmak, 2008). Furthermore, zinc may be required for chlorophyll synthesis, pollen function and fertilization (Kaya and Higgs, 2002; Pandey et al., 2006). Low solubility of $\mathrm{Zn}$ in soils rather than low total amount of $\mathrm{Zn}$ is the major reason for the widespread occurrence of $\mathrm{Zn}$ deficiency problem crop plants (Cakmak, 2008).

Zinc nutritional status of plants may affect the drought sensitivity of plants in different ways. Zinc is involved in detoxification of Reactive Oxygen Species (ROS) and it is also important for reducing the production of free radicals by superoxide radical producing enzymes (Cakmak et al., 1989; Cakmak, 2000). An adequate $\mathrm{Zn}$ nutrition has also protective effects on photoxidative damage catalyzed by ROS in chloroplasts (Cakmak, 2000, Wang and Jin, 2005). Drought stress represents an oxidative stress and kills plants by inducing production of ROS, especially during photosynthesis (Selote et al., 2004, Goodman and Newton, 2005). It is, therefore, likely that drought stress-related production of ROS and sensitivity of plants to photoxidative damage in chloroplasts are additionally accentuated when plants would simultaneously suffer from $\mathrm{Zn}$ deficiency stress.

Foliar-applied nutrients have limited direct use for enhancement of stress resistance mechanisms in field crops. Among the micronutrients, $\mathrm{Zn}$ and $\mathrm{Fe}$ nutrition can affect the susceptibility of plants to drought stress (Sultana et al., 2001; Khan et al., 2003; Cakmak, 2008). Foliar application of zinc greatly affects plant growth and crop production. It is, therefore, important to study the efficiency of foliar application of zinc on yield of wheat under water stressed condition at different growth stages of the crop. The present study was, therefore, undertaken a) to know the effect of foliar application of zinc on yield of wheat 
grown by skipping irrigation and b) to find out the optimum foliar dose of $\mathrm{Zn}$ application for sustainable yield of wheat.

\section{Materials and Method}

A field experiment was carried out in the micronutrient experimental field of Soil Science Division, Bangladesh Agricultural Research Institute located at $23^{\circ} 59^{\prime} 26^{\prime \prime} \mathrm{N}$ and 90²4'52" E., Grey Terrace Soil of Joydebpur, Gazipur (AEZ28) on 27 November, 2013 with a view to studying the effect of foliar application of zinc on yield of wheat grown by skipping irrigation. The experiment was laid out in a split plot design with three replications. Irrigation was assigned in a main plot and foliar application in the subplot. Wheat (Triticum aestivum var. BARI Gom 25) was used in the experiment.

There were sixteen treatment combinations comprising of four irrigation treatments i.e., $\mathrm{T}_{1}$ : regular irrigation: irrigation at crown root initiation stage, booting stage and grain filling stage, $\mathrm{T}_{2}$ : skipping one irrigation at crown root initiation stage, $\mathrm{T}_{3}$ : skipping one irrigation at booting stage, $\mathrm{T}_{4}$ : skipping one irrigation at grain filling stage and four levels of foliar spray of zinc i.e., $\mathrm{Zn}_{0}$ : control, $\mathrm{Zn}_{1}: 0.02 \%, \mathrm{Zn}_{2}: 0.04 \%$ and $\mathrm{Zn}_{3}: 0.06 \%$ foliar application of $\mathrm{Zn}$. Irrigation water was applied to the field condition in each plot as per treatment. Foliar application of zinc was done during the skipping irrigation at respective days. Zinc Sulphate Monohydrate $\left(\mathrm{ZnSO}_{4} \cdot \mathrm{H}_{2} \mathrm{O}\right)$ was used as sources of $\mathrm{Zn}$. Urea, triple supper phosphate, muriate of potash, gypsum and boric acid were used as sources of N, P, K, S and B, respectively. Fertilizers were applied based on BARC Fertilizer Recommendation Guide-2012. All PKSB and half of N were applied at the final land preparation and the remaining half of $\mathrm{N}$ was applied before booting stage. Initial properties of the soil samples of experimental field are presented in Table 1. Weather data during the crop growth period was presented in Fig.1. Wheat seeds were sown directly on 27 November, 2013 and the crops were harvested on 21 March, 2014 at full maturity. Ten plants from each plot were sampled randomly for collection of different plant characters and yield attributes. Data on yield and yield contributing characters such as plant height $(\mathrm{cm})$, spike length $(\mathrm{cm})$, grain spike ${ }^{-1}, 100$ grain wt, yield $\left(\mathrm{t} \mathrm{ha}^{-1}\right)$ were recorded. Plants of $1 \mathrm{~m}^{2}$ area from each plot were selected for data collection. Data on yield and yield contributing parameters were recorded and statistically analyzed with the help of statistical package MSTAT-C and mean separation was tested by Duncan's Multiple Range Test (DMRT) at 5\% level of probability.

\section{Determination of $\mathbf{Z n}$ content in wheat grain}

One gram of each sample was weighed into $50 \mathrm{ml}$ beaker, followed by the addition of $10 \mathrm{ml}$ mixture of analytical grade acids $\mathrm{HNO}_{3}: \mathrm{HCIO}_{4}$ in the ratio 5:1, and left overnight for complete contact of material. Next day, the digestion was 
performed at a temperature of about $190{ }^{\circ} \mathrm{C}$ for $1.5 \mathrm{~h}$. After cooling, the samples were transferred into $100 \mathrm{ml}$ volumetric flask and solution was made up to a final volume raised up to the mark with distilled water. The metal concentrations were determined by atomic absorption spectrometry using a Zeenit model 700 Atomic Absorption Spectrophotometer (AAS). Analysis of each sample was carried out three times to obtain representative results and the data reported in $\mu \mathrm{g} \mathrm{g}^{-1}$ (on a dry matter basis).

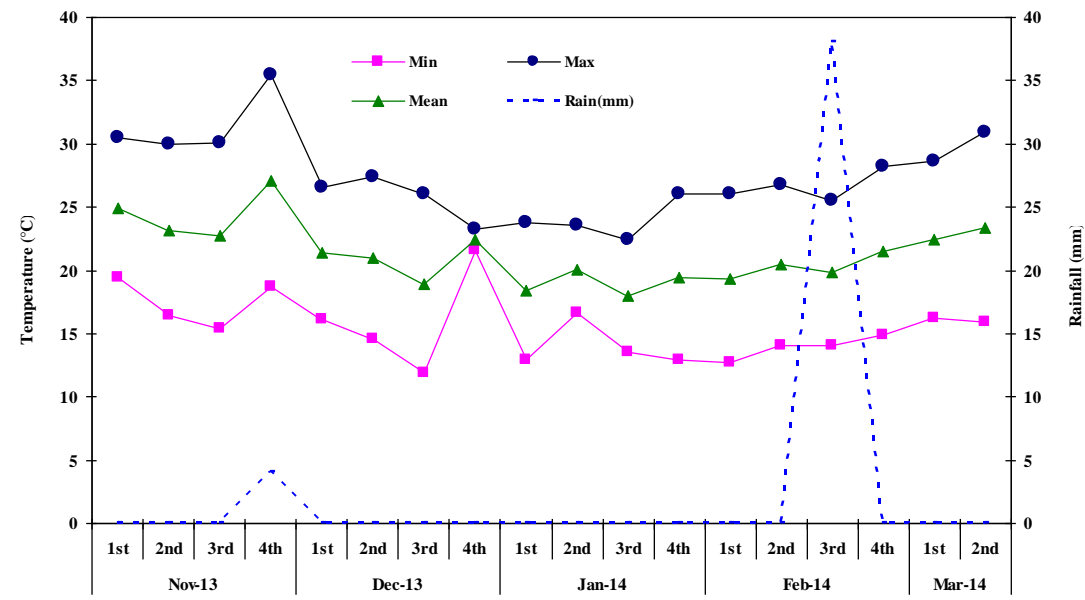

Fig. 1. Rainfall, minimum, maximum and mean temperature during growing period.

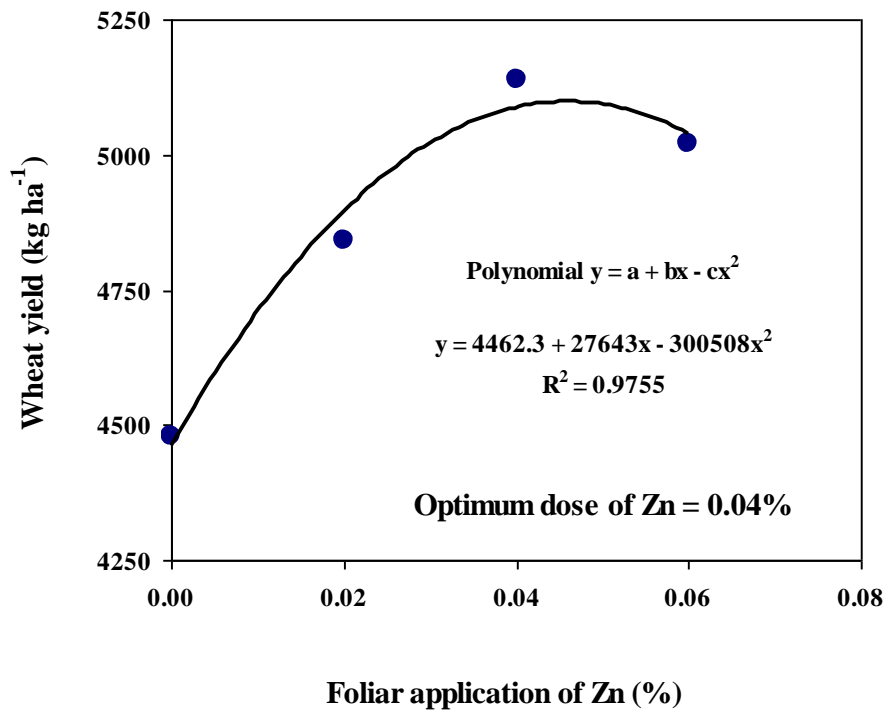

Fig. 2. Response of wheat to foliar application of Zn. 


\section{Results and Discussion}

\section{Effect of irrigation}

The effect of irrigation on the grain yield and yield components of wheat has been shown in Table 3. The highest grain yield $\left(5.29 \mathrm{t} \mathrm{ha}^{-1}\right)$ was obtained with regular irrigation $\left(\mathrm{T}_{1}\right)$, which was identical with skipping irrigation at heading and flowering stage $\left(\mathrm{T}_{4}\right)$. The lowest yield $\left(4.33 \mathrm{t} \mathrm{ha}^{-1}\right)$ was obtained from skipping irrigation at crown root initiation stage $\left(T_{2}\right)$, which was significantly lower than other treatments. This finding revealed that crown root initiation was the most critical stage for irrigation and its omission at this stage reduced the grain yield of 33 to $42 \%$ which was supported by Cheema et al. (1973). Crown root initiation (CRI) stage is the most critical stage for irrigation in wheat because any shortage of moisture at this stage results in less tillering and great reduction in yield. Bajwa et al. (1993) reported that number of tillers improved with irrigation at crown root stage and better grain yield was recorded with irrigation at crown root and booting stage.

\section{Effect of foliar application of zinc}

Foliar application of zinc played a significant role in the yield and yield components of wheat (Table 2). Yield components were influenced significantly due to foliar application of $\mathrm{Zn}$. The grain yield of wheat increased significantly due to added zinc up to 0.04\%. Kaya and Higgs (2002) and Cakmak (2008) reported that zinc plays an important role in the production of biomass. Firstly, $\mathrm{Zn}$ is involved in detoxification of Reactive Oxygen Species (ROS) and in this respect may play a protective role in preventing photoxidative damage catalyzed by ROS in chloroplasts (Cakmak, 2000; Cakmak and Römheld, 1997; Ducic and Polle, 2005). Secondly, this micronutrient might greatly contribute to droughtstress tolerance by protection against oxidative damage of membranes (Cakmak, 2000; Cakmak and Römheld, 1997; Ducic and Polle, 2005).The highest yield $\left(5.14 \mathrm{t} \mathrm{ha}^{-1}\right)$ was found with $0.04 \%$ foliar application of $\mathrm{Zn}$ which was higher than the rest of the doses. There was no significant difference between $0.02 \%$ and $0.06 \%$ foliar application of $\mathrm{Zn}$.

\section{Interaction effects of irrigation and foliar application of zinc}

The interaction effect between irrigation and foliar application of zinc on the yield and yield components of wheat was significant (Table 3 ). The highest grain yield $\left(5.59 \mathrm{t} \mathrm{ha}^{-1}\right)$ was recorded in regular irrigation $\left(\mathrm{T}_{1}\right)$ with $0.04 \%$ foliar application of zinc which was statistically with $\mathrm{T}_{4}$ treatment (skipping irrigation at grain filling stage). Skipping irrigation at crown root initiation (CRI) stage of growth caused the reduction in all yield components and grain yield of wheat. This might be due to reduced crown root development which decreased the grain 
SULTANA et al.

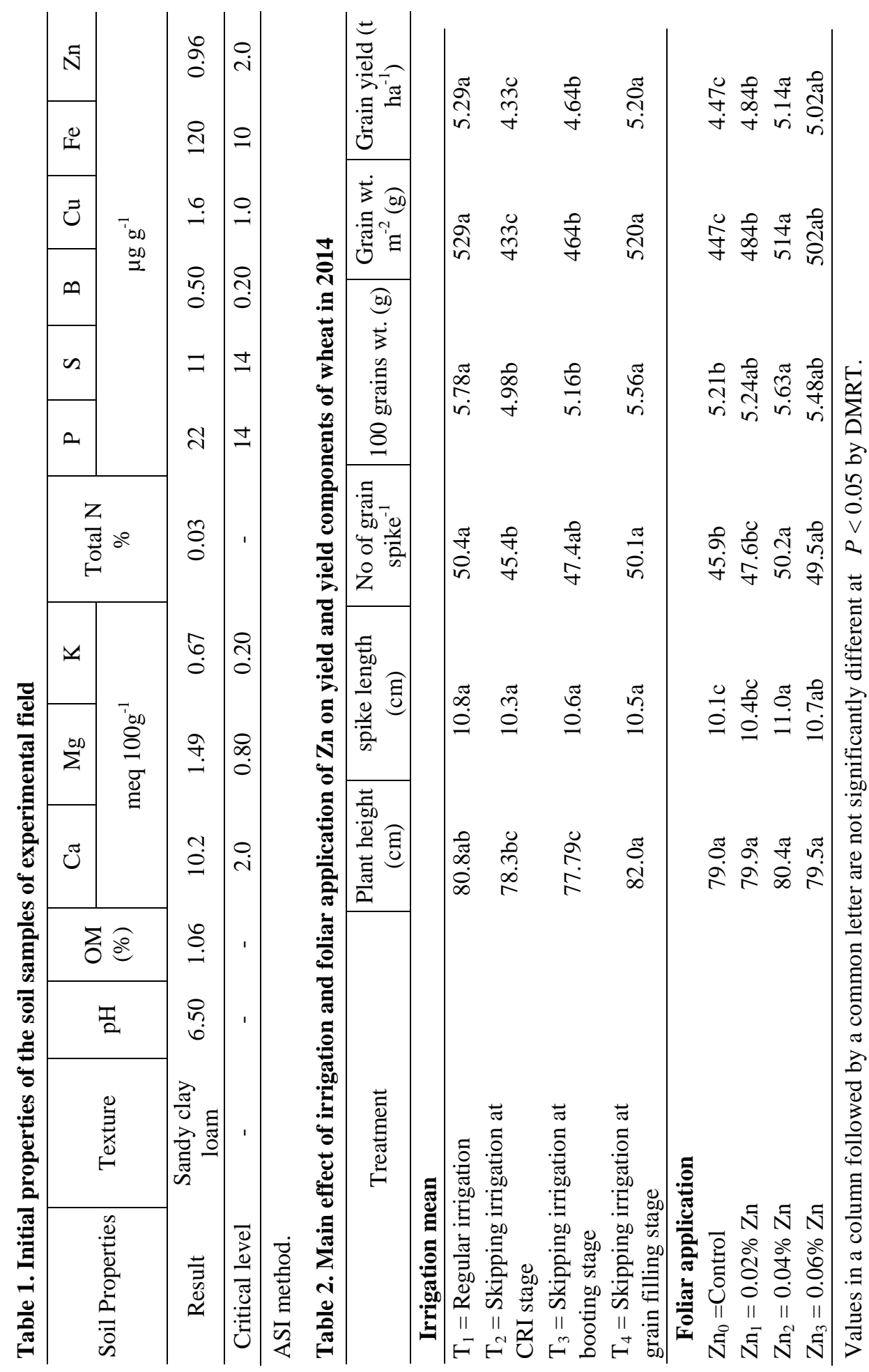




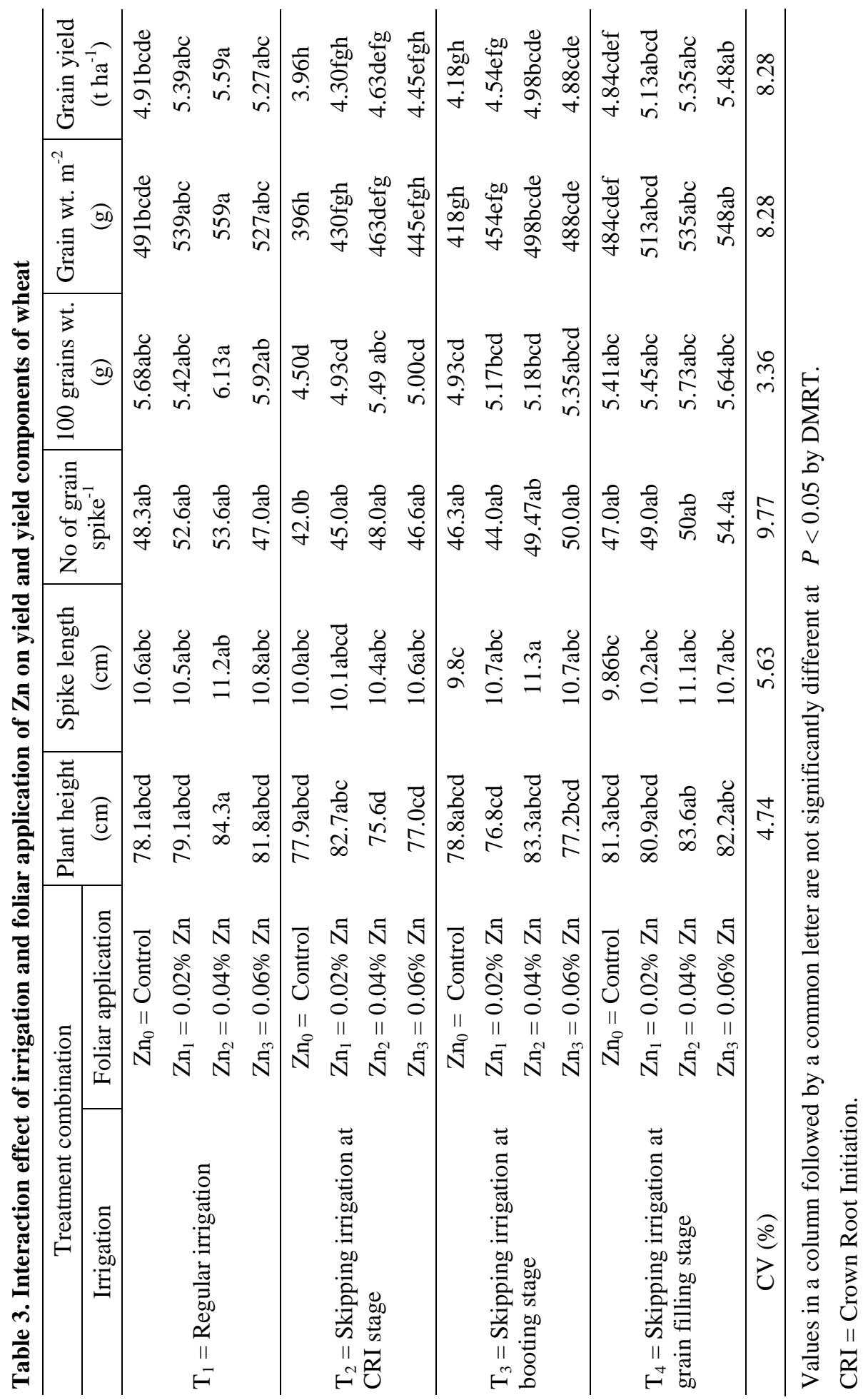


yield significantly. This result is in agreement with Thalooth et al. (2006) who reported that missing one irrigation at any stages of growth significantly reduced yield and yield components as well as photosynthetic pigments content as compared with regular irrigation. Skipping irrigation at flowering and heading stage with $0.04 \%$ foliar application of zinc gave the identical yield in regular irrigation (crown root initiation, booting stage, flowering and heading stage) with $0.04 \%$ and $0.06 \%$ foliar application of zinc. Timing of foliar $\mathrm{Zn}$ application is an important factor determining the effectiveness of the foliar applied $\mathrm{Zn}$ fertilizers in increasing grain $\mathrm{Zn}$ concentration. It is expected that large increases in loading of $\mathrm{Zn}$ into grain can be achieved when foliar $\mathrm{Zn}$ fertilizers are applied to plants at a late growth stage. Ozturk et al. (2006) studied changes in grain concentration of $\mathrm{Zn}$ in wheat during the reproductive stage and found that the highest concentration of $\mathrm{Zn}$ in grain occurs during the milk stage of the grain development. Results showed a high potential of $\mathrm{Zn}$ fertilizer strategy for rapid improvement of grain $\mathrm{Zn}$ concentrations, especially in the case of late foliar $\mathrm{Zn}$ application. Khan et al. (2010) reported that foliar application of zinc at reproductive growth stage increased grain and straw yield significantly in wheat. Foliar application of crop nutrients at latter stages will ensure better crop nutrition at anthesis and grain filling stage which in turn may result in increased grain weight. These results are in agreement with those of Soylu et al. (2005) who reported significant variations for 1000 grains weight for foliar application of boron. Similarly Kenbaev and Sade (2002) and Hosseini (2006) reported improvement in yield components for application of zinc. Moreover, zinc by its participation in the action of superoxide dismutase (SOD) enzyme, may contribute to drought stress tolerance (Bagci et al., 2007).

\section{Zn content and uptake by wheat grain}

The concentration of $\mathrm{Zn}$ in wheat grain ranged from 46.5 to $63.0 \mathrm{ppm}$ (Table 4). Skipping irrigation at grain filling stage treatment $\left(\mathrm{T}_{4}\right)$ under foliar applied different zinc concentrations showed significantly higher content of $\mathrm{Zn}$ in grain compared to other irrigation treatment with different size concentrations that were foliar sprayed. Consequently the uptake of $\mathrm{Zn}$ was higher in $\mathrm{T}_{4}$ treatment compared to other treatments under different size concentrations which were foliar sprayed.

\section{Economic performance:}

The economic performance of different treatments is presented in Table 5. The highest gross return, gross margin and BCR (TK. $87713 \mathrm{ha}^{-1}$, Tk. $69257 \mathrm{ha}^{-1}$ and 4.75 , respectively) was recorded in $\mathrm{T}_{4} \mathrm{Zn}_{3}$ concentration. The lowest gross return, gross margin and BCR (TK. $63360 \mathrm{ha}^{-1}$, Tk. $45044 \mathrm{ha}^{-1}$ and 3.46, respectively) was found in $\mathrm{T}_{2} \mathrm{Zn}_{0}$ combination. 


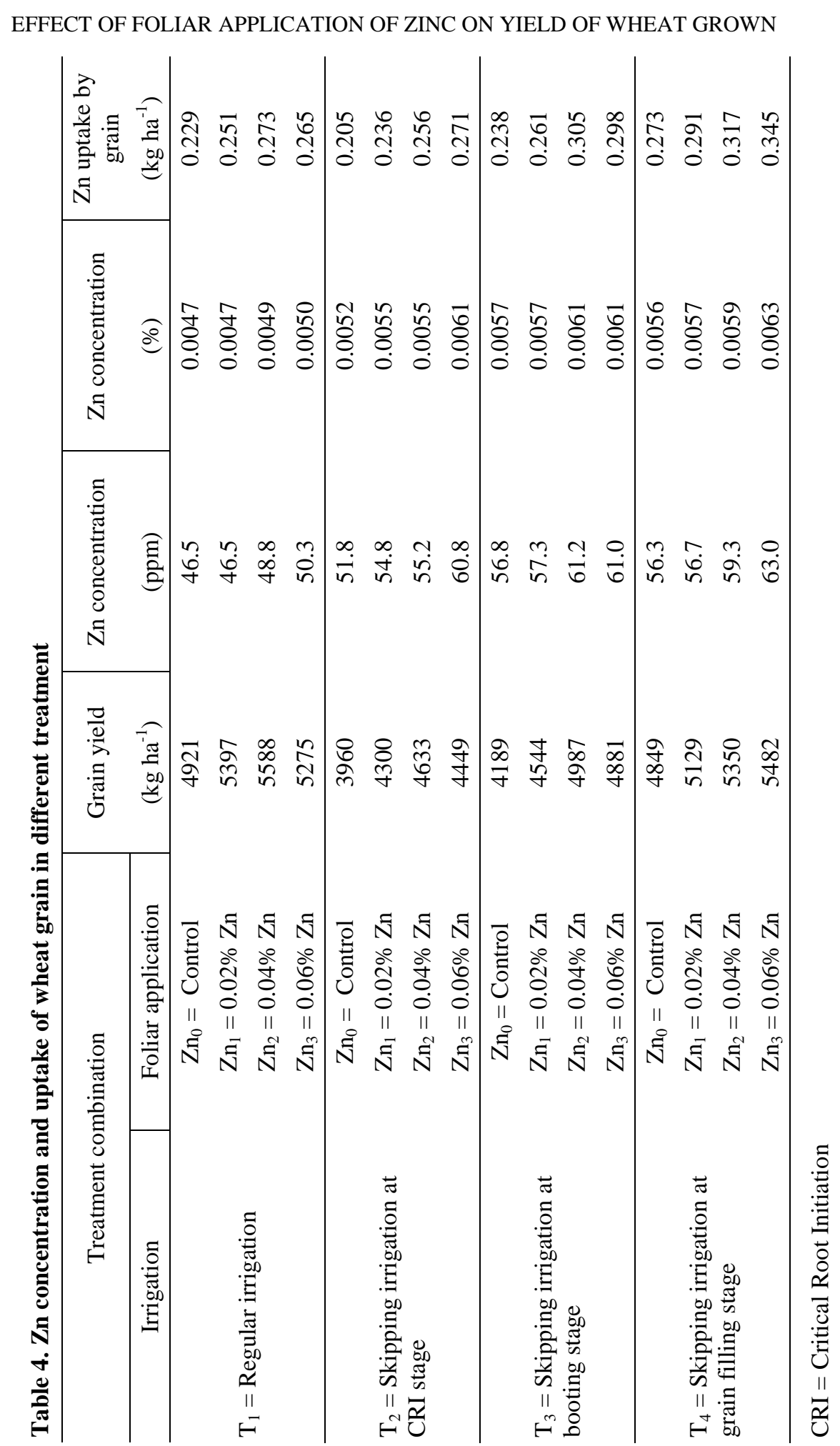




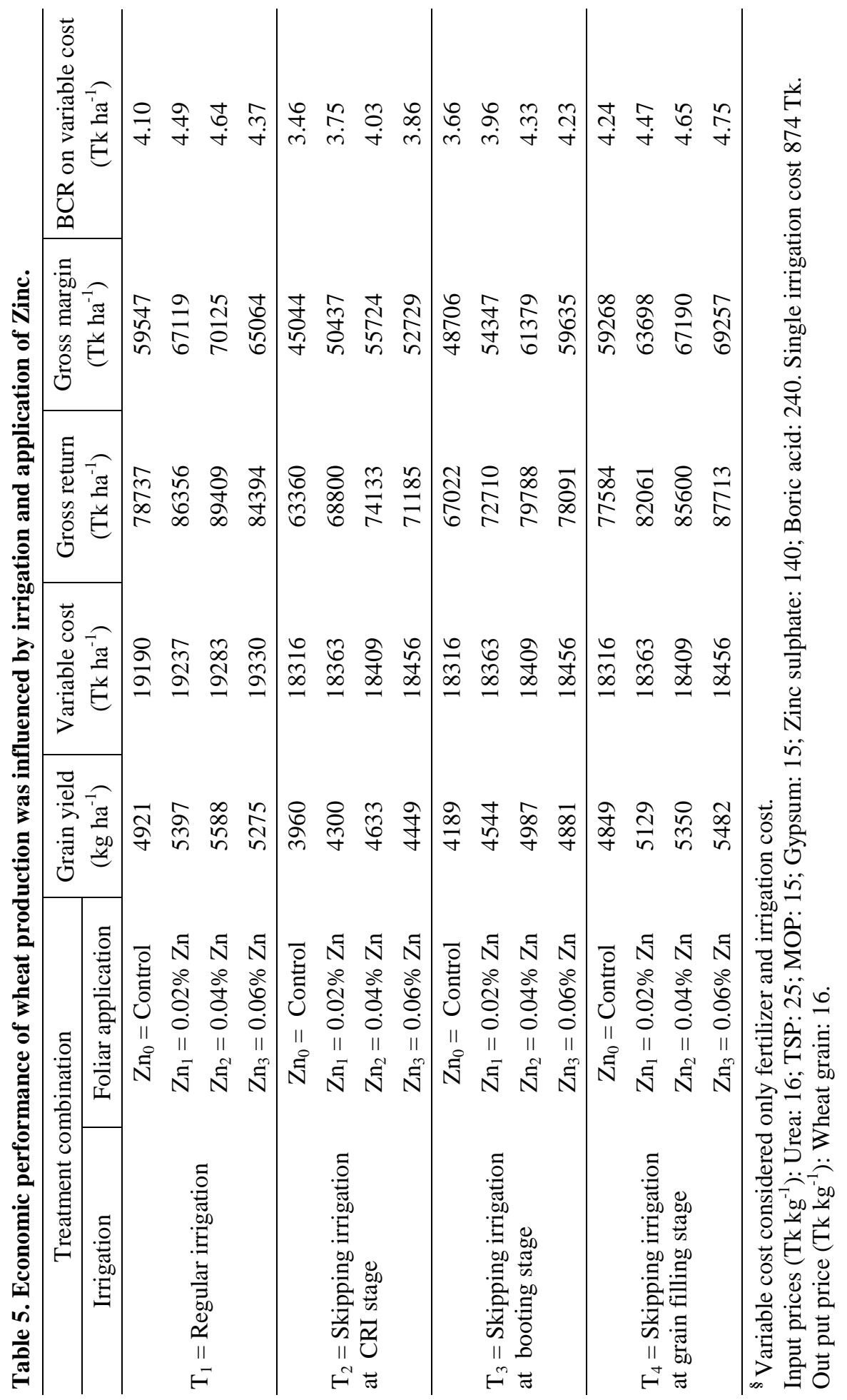




\section{Response function}

A quadratic relationship was observed between grain yield of wheat and foliar application of zinc (Fig. 2). From the regression equation, the optimum dose of foliar application of zinc appeared as $0.046 \%$. So foliar application of $0.04 \% \mathrm{Zn}$ may be considered as the best suitable dose for grain yield of wheat.

\section{Conclusion}

It can be concluded that wheat plants grown by skipping irrigation with foliar application of zinc counteracted the adverse effect of water deficit on the yield, especially at later stages of growth and helped the plants grow successfully under these unfavorable conditions. According to the results of the experiment, using $0.04 \%$ zinc as foliar application increased grain yield compared to all other treatments.

\section{References}

Bagci, S. A., H. Ekiz, A. Yilmaz and I. Cakmak. 2007. Effects of zinc deficiency and drought on grain yield of field-grown wheat cultivars in Central Anatolia J. Agron. \& Crop Sci. 193: 198-206.

Bazwa, M. A. M. H. Choudhury and A. Sattar. 1993. Influence of different irrigations regimes on yield and yield components of wheat. Pakistan J. Agric. Res. 14(4):361365.

Cakmak, I. 2008. Enrichment of cereal grains with zinc: Agronomic or genetic biofortification? Plant Soil. 302: 1-17.

Cakmak, I. 2000. Possible roles of zinc in protecting plant cells from damage by reactive oxygen species. New Phytol. 146: 185-205.

Cakmak, I. and V. R. omheld, 1997. Boron deficiency induced impairments of cellular functions in plants. Plant Soil. 193:71-83.

Cakmak, I., H. Marschner and Bangert, F. (1989). Effect of zinc nutritional status on growth, protein metabolism and levels of indole-3-acetic acid and other phytohormones in bean (Phaseolus vulgaris L.). J. Exp. Bot. 40:404-412.

Cheema, S. S., K. K. Dhingra and G. S. Gill. 1973. Effect of missing irrigations on the growth of dwarf wheat. J. Res. Punjab Agric. Univ. 10(1):41-44.

Ducic, T., A. Polle. 2005: Transport and detoxification of manganese and copper in plants. Braz. J. Plant Physiol. 17: 103-112.

Ekiz, H., S. A. Bagcı, A. S. Kıral, S. Eker, I. Gu“ ltekin, A. Alkan and I. Cakmak. 1998. Effects of zinc fertilization and irrigation on grain yield and zinc concentration of various cereals grown in zinc-deficient calcareous soils. J. Plant Nutr. 21: 22452256.

Goodman, B. A., and A. C. Newton. 2005. Effects of drought stress and its sudden relief on free radical processes in barley. J. Sci. Food Agric. 85: 47-53. 
Grotz, N. and M. L. Guerinot. 2006. Molecular aspects of $\mathrm{Cu}$, Fe and $\mathrm{Zn}$ homeostasis in plants. Biochim. Biophys. Acta. 1763: 595-608.

Hosseini, S.M. 2006. Zinc- Boron interaction effects on yield, yield components and chemical composition of wheat. The 18th World Congress of Soil Sci.

Kaya, C. and D. Higgs. 2002. Response of tomato (Lycopersicon esculentum L.) cultivars to foliar application of zinc when grown in sand culture at low zinc. Sci. Hortic. 93: 53-64.

Kenbaev B. and B. Sade. 2002. Response of field-grown barley cultivars grown on zincdeficient soil to zinc application. Comm. Soil Sci. Plant Anal. 33(3-4): 533-5544.

Khan S, K.J. Mirza, F. Anwar, M. Z. Abdin. 2010. Development of RAPD markers for authentication of Piper nigrum . Environment \& International Journal of Science and Technology. 5: 53-62.

Khan, H. R., G. K. McDonald and Z. Rengel. 2003: Zn fertilization improves water use efficiency, grain yield and seed $\mathrm{Zn}$ content in chickpea. Plant Soil. 249: 389-400.

Ozturk L, MA Yazici, C Yucel, A Torun, C Cekic, A Bagci, H Ozkan, HJ Braun, Z Sayers, I. Cakmak. 2006. Concentration and localization of zinc during seed development and germination in wheat. Physiol. Plant. 128: 144-152.

Pandey, N., G. C. Pathak and C. P. Sharma. 2006. Zinc is critically required for pollen function and fertilisation in lentil. J. Trace Elem. Med. Biol. 20: 89-96.

Selote, D. S., S. Bharti and R. Khanna-Chopra. 2004. Drought acclimation reduces $\mathrm{O}_{2-}$ accumulation and lipid peroxidation in wheat seedlings. Biochem. Biophys. Res. Commun. 314: 724-729.

Soylu S, B.Sade, A.Topalv, N. Akgun and S. Gezgin. 2005. Responses of irrigated durum and bread wheat cultivars to boron application in low boron calcareous Soil. Turk. J. Agric. 29: 275-286.

Sultana, N., T. Ikeda and M. A. Kashem. 2001. Effect of foliar spray of nutrient solutions on photosynthesis, dry matter accumulation and yield in seawater-stressed rice. Environ. Exp. Bot. 46: 129-140.

Thalooth, A.T., M.M. Tawfik and H. M. Mohamed. 2006. A Comparative Study on the effect of foliar application of zinc, potassium and magnesium on growth, yield and some chemical constituents of mungbean plants grown under water stress conditions. World J. Agril. Sci. 2(1): 37-46.

Wajid, A., A. Hussain, A. Ahmed, M. Rafiq, A.R. Goheer and M. Ibrahim. 2004. Effect of sowing date and plant density on growth, light interception and yield of wheat under semi arid condition. Intl. J.Agric. Biol. 6: 1119-1123.

Wang, H., and J. Y. Jin. 2005: Photosynthetic rate, chlorophyll fluorescence parameters, and lipid peroxidation of maize leaves as affected by zinc deficiency. Photosynthetica. 43: 591-596. 